Atos oficiais:

\title{
ATOS DA ADMINISTRAÇÃO FEDERAL
}

\author{
DECRETO-LEI N. 6.527 - DE 24 DE
}

MAIO DE 1944

Cria, na Prefeitura do Distrito Federal, a Escola Técnica de Assistência Social e dá outras providências.

O Presidente da República, usando da atribuição que lhe confere o artigo 180 , da Constituição, e nos termos do art. 31 do Decreto-lei n. ${ }^{\circ}$ 96, de 22 de dezembro de 1937, decreta:

Art. 1. ${ }^{\circ}$ Fica criada, na Secretaria Geral de Saúde e Assistência da Prefeitura do Distrito Federal, a Escola Técnica de Assistência Social, destinada ao preparo de visitadoras sociais, educadoras domiciliares, puericultoras e nutricionistas.

$\S 1 .^{\circ}$ - Poderá, outrossim, a referida Escola, aperfeiçoar os conhecimentos do pessoal já em função nos serviços dessa natureza, subordinados à Prefeitura do Distrito Federal.

$\S 2 .^{\circ}$ - A Escola Técnica de Assistência Social poderá ainda, promover o preparo das atendentes em geral.

Art. $2^{\circ}$ A Escola Técnica de Assistência Social ficará diretamente subordinada ao Secretário Geral de Saúde e Assistência.

Art. 3. ${ }^{\circ}$ Para os cursos de visitadoras sociais educadoras domiciliares puericultoras e nutricionistas, será exigido como base de conhecimento geral, o certificado de licença ginasial.

Art. $4 .^{\circ} \mathrm{O}$ ensino nos diversos cursos da Escola será ministrado de acordo com o Regulamento a ser baixado oportunamente.

Paragrafo único - Para o curso de atendentes, o Regulamento da Escola estabelecerá as condições de matrícula.

Art. 5. ${ }^{\circ}$ Os serviços da Escola Técnica de Assistência Social serão superintendidos por um Diretor, devendo a escolha recair em pessoa especializada em assuntos relacionados com serviço social, com prática de ensino em cursos semelhantes e tirocínio em trabalhos de assistência social.

Art. $6 .^{\circ} \mathrm{O}$ corpo docente, o pessoal técnico auxiliar e o pessoal administrativo, serão compostos por serventuários da Prefeitura do Distrito Federal.

Parágrafo único - A Prefeitura do Distrito Federal poderá, em razão das conveniências do serviço ou das necessidades do ensino, contratar para os cursos da Escola Técnica de Assistência Social, professores, que regerão uma ou mais cadeiras, assim como pessoal para os quadros técnico, auxiliar e administrativo.

Art. $7^{\circ}$ As atribuições do Diretor da Escola bem como as do corpo do- 
REVISTA BRASILEIRA DE ESTUDOS PEDAGÓGICOS

tente e do pessoal administrativo e técnico auxiliar serão discriminadas no Regulamento da Escola.

Art. $8 .^{\circ}$ Para os efeitos do art. $5 .^{\circ}$ deste Decreto-lei, fica criado no Quadro Permanente da Prefeitura um cargo isolado de Diretor de Estabelecimento, padrão 03 , de provimento em comissão.

Art. 9. ${ }^{\circ}$ Nos têrmas do item III, do art. 7." do Decreto-lei n. ${ }^{\circ}$ 96, de 22 de dezembro de 1937 , o Prefeito do Distrito Federal baixará o Regulamento para a Escola Técnica de Assistência Social.

Art. 10. Fica o Prefeito do Distrito Federal autorizado a abrir o crédito necessário para atender, no corrente exercício, às despesas decorrentes do presente Decreto-lei.

Art. 11. O presente Decreto-lei entrará em vigor na data de sua publicação.

Art. 12. Revogam-se as disposições em contrário.

Rio de Janeiro, 24 de maio de 1944, 123. ${ }^{\circ}$ da Independência e $56 .^{\circ}$ da República.

GetUlio VARGAS.

Alexandre Marcondes Filho.

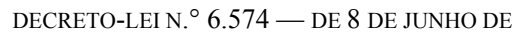

Dispõe sobre a definitiva localização da Universidade do Brasil e declara de utilidade pública os prédios c terrenos da Vila Valqueire (antiga Fazenda do Valqueire), no Distrito Federal.

O Presidente da República; Considerando a conveniência de dar à Universidade do Brasil localização mais adequada do que a prevista na Lei ${ }^{\circ}{ }^{\circ} 452$, de 5 de julho de 1937 ;

Tendo em vista o disposto no art. $5 .^{\circ}$ do Decreto-lei n. ${ }^{\circ} 3.365$, de 21 de junho de 1941;

E usando da atribuição que lhe confere o art. 180 da Constituição, decreta :

Art. $1 .^{\circ}$ Os estabelecimentos de ensino e os demais serviços componentes da Universidade do Brasil, a serem reunidos em cidade universitária, edifi-car-se-ão nos terrenos da Vila Valqucire (antiga Fazenda do Valqueire), no Distrito Federal.

Parágrafo único. Fica revogado o parágrafo único do art. 10 da Lei número 452, de 5 de julho de 1937.

Art. 2. ${ }^{\circ}$ Fica declarada a utilidade pública dos prédios e terrenos compreendidos $\mathrm{cm}$ toda a área da Vila Valqueire (antiga Fazenda do Valqueire), no Distrito Federal, necessários à construção da Universidade do Brasil.

Art. 3. ${ }^{\circ} \mathrm{O}$ presente Decreto-lei entrará em vigor na data de sua publicação.

Art. $4 .^{\circ}$ Revogam-se as disposições em contrário.

Rio de Janeiro, 8 de junho de 1944, 123.. ${ }^{\circ}$ da Independencia e $56^{\circ}$ da República.

Getulio VARGAS.

Gustavo Capanema

PORTARIA MINISTERIAL N. 276, DE 6 DE JUNHO DE 1944

Dispõe sobre os preços dos estabelecimentos de ensino

O Ministro de Estado da Educação e Saúde,

Considerando que a fixação de preços dos estabelecimentos de ensino, 
medida que tomou em caráter transitório o Coordenador da Mobilização Econômica, pela Portaria n. ${ }^{\circ} 218$. de 13 de abril de 1943, é de evidente interesse público;

Considerando ser medida de justiça que o preceito estabelecido pelo Coordenador da Mobilização Econômica somente vigore a partir da data de sua publicação;

Resolve, de acordo com o Coordenador da Mobilização Econômica:

Art. 1. Os estabelecimentos de ensino de todo o país não poderão elevar os preços cobrados a seus alunos além dos limites em vigor a 17 de abril de 1944.

Art 2. O Departamento Nacional de Educação examinará desde logo o aumento de preços, verificado em cada estabelecimento de ensino secundário e de ensino superior entre o ano escolar de 1943 e o de 1944, e representará ao Ministro da Educação contra a' majoração porventura excessiva.

Rio de Janeiro, 6 de junho de 1944. 